\title{
Socioeconomic dynamics of vermicomposting systems in Lebanon
}

\author{
Sara Moledor, ${ }^{a}$ Ali Chalak, ${ }^{\mathrm{b}}$ Monika Fabian, ${ }^{\mathrm{b}}$ and Salma N. Talhouk ${ }^{\mathrm{b} *}$
} American University of Beirut

Submitted July 20, 2015 / Revised January 22 and April 12, 2016 / Accepted April 12, 2016 /

Published online September 6, 2016

Citation: Moledor, S., Chalak, A., Fabian, M., \& Talhouk, S. N. (2016). Socioeconomic

dynamics of vermicomposting systems in Lebanon. Journal of Agriculture, Food Systems, and

Community Development, 6(4), 145-168. http://dx.doi.org/10.5304/jafscd.2016.064.007

Copyright (C) 2016 by New Leaf Associates, Inc.

\begin{abstract}
Vermicomposting is a sustainable means of waste management, rural development, and ecoagricultural improvement. This study examines its potential in Lebanon, specifically from a microenterprise angle. First, we conducted four interviews with rural residents already practicing vermicomposting, and the interviews reveal that community-scale vermicomposting enterprises hold considerable promise. This positive feedback led us to undertake a feasibility study that examines the economic dynamics of a micro-vermicompost
\end{abstract}

${ }^{a}$ Graduate of Faculty of Agriculture and Food Science, American University of Beirut.

${ }^{b}$ Faculty of Agriculture and Food Science, American University of Beirut

* Corresponding author: Salma N. Talhouk, Professor, American University of Beirut; Bliss Street, 11-0236; Riad El-Solh 11072020, Lebanon; +961-1-374374 ext. 4508/4578; ntsalma@aub.edu.lb

1 All values in this paper are in US\$. industry across three sectors. We calculate that the government or municipalities who pay for waste management stand to save $\$ 190^{1}$ per ton of vermicompost produced due to a reduction in the amount of solid waste requiring collection, handling, and processing. According to the microenterprise model proposed here, one ton of vermicast could sell for $\$ 1,970$. The farmer/ consumer can expect approximately $\$ 110-\$ 350$ in additional income from applying one ton of vermicompost due to offset costs of traditional fertilizer and pesticides, reduced irrigation costs, and foregone illness expenses (associated with

\section{Acknowledgements}

This project was funded by the Department of Landscape Design and Ecosystem Management and by a grant from the Samir and Claude Abillama Eco-entrepreneurship award. This paper is derived from the dissertation submitted by S.M. in partial fulfillment of the requirements for the MSc degree at the American University of Beirut. We would like to thank Professor Jad Chaaban for his contribution to the study, the Abillama family for their generous support, and the people who form the basis of the case studies for their involvement in the vermicomposting project. 
pesticide exposure). Combined, the value of one ton of vermicompost is estimated between $\$ 2,280$ and $\$ 2,510$. It becomes clear that rurally based vermicomposting microenterprises offer immediate socioeconomic advantages, such as those mentioned above, as well as a host of indirect advantages, including environmental improvements, support of local economies, and a more wholesome and locally based food system. Considering that the body of knowledge surrounding vermicomposting is largely science-oriented, this study is significant in its contribution to the oftenoverlooked aspects of socioeconomics and practical application.

\section{Keywords}

Vermicomposting; Earthworms; Lebanon; Community Waste Management; Microenterprise

\section{Introduction}

Sustainability as a concept began to permeate the public sphere in the 1970s and '80s, but was first directly addressed in the Brundtland Commission and its report Our Common Future in 1987. "Sustainable development" was described as "development that meets the needs of the present without compromising the ability of future generations to meet their own needs" (Bruntland Report, 1987, “Towards Sustainable Development," para. 1). This report was the first of its kind to recognize that poverty is not merely economic and that the environment is not merely biophysical; instead, they are inherently interconnected. In the wake of this important, but admittedly ambiguous, description, efforts refocused on deciphering, prescribing, and advocating a more comprehensive definition of sustainability. The 2002 World Summit on Sustainable Development expanded the concept based on three "interdependent and mutually reinforcing" pillars of sustainability: economic development, social development, and environmental protection (Gibson, 2006; Robert, Parris, \& Leiserowitz, 2005).

In this study, we focus on the biotechnology commonly known as vermicomposting. Vermicomposting harnesses and maximizes the earthworm's natural digestive cycle to transform waste into a value-added resource (Munnoli, Teixeira da
Silva, \& Bhosle, 2010). Worms eat roughly their full weight in waste per day (Munnoli et al., 2010; Riggle \& Holmes, 1994; Sinha, Agarwal, Chauhan, Chandran, \& Kiranbhai Soni, 2010) and produce large quantities of manure composed of microorganisms, inorganic minerals, enzymes, and organic matter (Gajalakshmi \& Abbasi, 2004). This end product, known as vermicast, is a highly valued natural soil fertilizer and pesticide (Jack \& Thies, 2006).

The use of vermicomposting as a means to recycle organic waste has been tested in different countries for different purposes and at different scales of operation. Vermicomposting has been examined as a means of municipal solid waste management in Argentina (Tognetti, Laos, Mazzarino, \& Hernandez, 2005; Tognetti, Mazzarino, Laos, 2007), in the Philippines, (Adorada, 2007), in India (Kumar, Jayaram, Somashekar, 2009; Purkayastha, 2012; Seenappa, 2011), and in Spain (Lleó, Albacete, Barrena, Font, Artola, \& Sánchez, 2013). It has been assessed for processing human biosolids (Doherty \& McKissick, 2000; Eastman et al., 2001) and organic industrial wastes, including manure from cattle breeding facilities (Lazcano, Gómez-Brandón, \& Domínguez, 2008), byproducts from the coffee industry (Murthy \& Naidu, 2012) and residues from palm oil mills (Singh, R. P., Embrandiri, Ibrahim, Esa, 2011). Other studies attest to the use of vermicomposting for the dairy, poultry, food, slaughterhouse, and olive oil industries (Munnoli et al., 2010).

The benefits of the vermicomposting process are many. As as a means of solid-waste management, earthworm processing reduces the volume of organic waste by approximately 50\% (Adhikary, 2012), is safe, hygienic, and scalable to fit any volume (Singh R. P., Singh, Araujo, Hakimi Ibrahim, Sulaiman, 2011). Evidence suggests that it is preferable to the more common and recognized practice of composting when there is a preference for a faster decomposition rate (Sinha, R., Herat, Agarwal, Asadi, \& Carretero, 2002), greater reduction of heavy metals (Singh, R. P., Singh, et al., 2011), and/or pathogen stabilization and lack of odors (Lazcano et al., 2008).

Secondly, adding vermicast to the soil improves its physical, chemical, and biological 
Journal of Agriculture, Food Systems, and Community Development

ISSN: 2152-0801 online

www.AgDevJournal.com

Table 1. Nitrogen (N), Phosphorous (P), and Potassium (K) Content of Container Media

\begin{tabular}{llll}
\hline Medium & $\begin{array}{c}\text { Total } \mathbf{N} \\
(\%)\end{array}$ & $\begin{array}{c}\text { Total P } \\
(\%)\end{array}$ & $\begin{array}{c}\text { Total K } \\
(\%)\end{array}$ \\
\hline Metro-Mix 360 & 0.43 & 0.15 & 1.59 \\
\hline Vermicompost (Food Wastes) & 1.80 & 0.4 & 1.1 \\
\hline Vermicompost (Pig Solids) & 2.36 & 4.5 & 0.4 \\
\hline Compost (Biosolids) & 3.7 & 1.7 & 0.6 \\
\hline Compost (Leaf Wastes) & 1.16 & 0.2 & 0.6 \\
\hline
\end{tabular}

Adapted from Atiyeh, Subler, Edwards, Bachman, Metzger, \& Shuster, 2000.

properties and also enhances its fertility (Singh, R. P., Singh, et al., 2011), while providing important nutrients to plants and stimulating plant growth (Jack \& Thies, 2006; Munnoli et al., 2010). Table 1 shows the nitrogen, phosphorous, and potassium content of potting soil treated with a standard inorganic fertilizer and various composts. Table 2 shows the wide variety of crops that have been shown to respond positively to vermicast, along with their recommended application rates.

Additionally, there is a growing body of evidence focused on the pesticide properties of vermicast. Adding vermicast to growth media has been shown to significantly suppress many diseases, including damping off (Pythium, Rhizoctonia), root rot (Phytophthera), sugar beet

Table 2. Recommended Vermicast Application Rate (tons/ha) per Crop

\begin{tabular}{lc}
\hline Crop & Rate/Th-1 \\
\hline Cereals & 5 \\
\hline Pulses & 5 \\
\hline Oil seeds & 12.5 \\
\hline Spices & 10 \\
\hline Vegetables & 12.5 \\
\hline Fruits & 7.5 \\
\hline Cash crops & $15-17.5$ \\
\hline Plantains & 7.5 \\
\hline Horticulture crops & $100-200$ g/tree \\
\hline Kitchen garden and pots & $50 \mathrm{~g} /$ pot \\
\hline
\end{tabular}

Source: Munnoli, P. M., Teixeira da Silva, J., \& Bhosle, S. (2010). Dynamics of the soil-earthworm-plant relationship: A review. Global Science Books. cyst nematode (Heterodera schachtii), and to deter such pests as aphids, mealy bugs, cucumber beetles, and tobacco hornworms (Moledor, 2014). Another study measured the decrease in albinism, injury, malformation, and Botrytis rot symptoms in strawberries and concluded that vermicompost can improve the marketable fruit yield by up to 58.6\% (Singh, R., Sharma, Kumar, Gupta, \& Patil, 2008). With both fertilizer and pesticide properties, vermicast is essentially a two-in-one soil amendment.

Although most literature is focused on the scientific side of vermicomposting, a few studies examine its economic prospects. Experiences in India and the Philippines reveal that the costbenefit ratios of vermicomposting enterprises range from 2.4 to 5.7 (indicating that even with a discount rate, every dollar of initial investment would produce a net benefit 2.4-5.7 times greater) (Adorada, 2007; Shivakumar, Mahajanashetti, Murthy, Basavaraja, Hawaldar, 2009). In many cases, vermicast production improved farmers' socioeconomic status, while the most innovative among them earned $\$ 750$ to $\$ 1,500$ per year from sales (Vermani, 2007). In many situations, however, vermicomposting is conducted as a public service and sales merely offset implementation costs.

Lebanon is located on the eastern shores of the Mediterranean Basin. It houses 38 permanent and seasonal flow rivers, and is considered a global biodiversity hotspot with an estimated floristic richness of 2,600 vascular plant species, of which $311(12 \%)$ are endemic (Myers, Mittermeier, Mittermeier, Da Fonseca, \& Kent, 2000). More than half the Lebanese population resides in cities and towns along the coast, while towns and villages in the mountains serve primarily as permanent residences for farming communities and as weekend and summer homes for city dwellers originating from these villages (Ministry of Environment [MoE], 2011).

Conditions in Lebanon are particularly conducive to a vermicomposting industry. A large 
fraction of the country's waste $(60 \%)$ is organic in nature (MoE, 2011), and the ideal vermicomposting worm (Eisenia fetida) is naturally present in Lebanese soils (Pavlícek, Csuzdi, Nevo, 2003). Additionally, the issue of sustainable waste management is especially salient currently. Beirut is undergoing a monumental waste disposal crisis following the closing of a critical landfill in July 2015, leaving the streets congested with garbage and sparking riots in protest of a dysfunctional government (Al Jazeera \& Agencies, 2015). In short, it is a critical time to explore waste management alternatives in Lebanon.

In light of this, the objective of this study is to evaluate the socioeconomic aspects of vermicomposting within rural communities of Lebanon and, more specifically, through the lens of decentralized microenterprises. The results from four case studies indicate that the social acceptability of and willingness to engage in vermicomposting activities are present and strong in Lebanon. This is then reinforced by a feasibility study that reveals vermicomposting presents significant economic opportunity.

\section{Methodology}

\section{Qualitative Study}

The qualitative study is composed of four interviews with vermicomposting practitioners in Lebanon that were conducted between October 2013 and February 2015. These interviews shed light on the backgrounds, experiences, and drives of the people who have undertaken this activity.

\section{Feasibility Study}

Positive results from the qualitative study warranted an economic study of vermicomposting potential. Our feasibility study includes a social cost-benefit analysis of vermicompost production and consumption to quantify the benefits to both the private sector (where it applies) and to the public at large. The analysis was not comprehensive; we chose variables based on available data and immediate impact from three sectors:

(1) Savings from improved waste management;

(2) Profits from vermicomposting microenterprise opportunities; and

(3) Agricultural benefits.

The feasibility study results were calculated in USD currency rather than Lebanese lira (or Lebanese pound) (LBP), in order to reach a wider audience.

\section{Calculation of $W$ aste Management Savings}

Although any sort of organic by-product can be vermicomposted, the model employed in the study uses residential food waste. Using kitchen waste as the fuel for the vermicompost process means that a certain quantity of waste is diverted from the waste stream. This is an environmental benefit in that less waste goes to the landfill; approximately half of Lebanon's municipal solid waste is landfilled, while approximately a quarter is disposed of in open dumps (MOE, 2010). This benefit is important, considering that the organic portion of a landfill is particularly undesirable for reasons of general site disamenity (odor, pest attraction), high moisture content, risk of leachate contamination, and tendency to harbor harmful pathogens and disease vectors. Landfill gasses that result from the decomposition of organic waste (mostly methane and carbon dioxide) are currently untapped for energy production in Lebanon and therefore represent added environmental disamenity (Clarke, 2000; Furedy \& Pitot, 2009).

Diverting the waste stream represents a financial benefit for the government, which currently pays private sanitation companies (Sukleen and its subsidiary, Sukomi) for service in the Beirut and Mount Lebanon regions. Outside these two regions, local municipalities generally manage their waste directly (MoE, 2011). In short, vermicomposting reduces waste management spending by government and municipalities and reduces environmental disamenity. Reduced spending and disamenity are the variables used to determine the value of diverting one ton of organic waste. See Appendix A for details of our calculations.

\section{Calculation of Enterprise Opportunities}

Vermicomposting as a small-scale enterprise has been reported to be a profitable, part-time activity (Adorada, 2007; Shivakumar et al., 2009). This part 
of the feasibility study attempts to quantify the production costs and anticipated revenue in a micro-cost analysis. First, the fixed, operational, and variable costs are estimated to determine the cost of producing one ton of vermicast. These data are presented in Appendix B. In the results section, these input costs are compared to the anticipated income, which elucidate the profitability of a vermicomposting enterprise.

\section{Calculation of Agricultural Benefits}

Taking a closer look at the agricultural benefits of vermicompost is pertinent not only in regard to its contribution to overall economic benefits, but also because this is the sector that will be creating demand for the product. If the net returns to the consumer (in this case, the farmer or gardener who purchases the product) are positive, then the potential market demand for vermicompost is established. Of course, there are many other factors at play, such as social stigmas and behavioral changes, which should be analyzed in future research. Our study, by addressing the economic viability of vermicomposting, establishes the minimum requirements for the vermicompost concept to succeed in recruiting new, entrepreneurial farmers as consumers.

The first variable in measuring vermicast benefits is increased water retention in the soil (Adhikary, 2012; Manivannan, Balamurugan, Parthasarathi, Gunasekaran, \& Ranganathan, 2009; Parthasarathi, Balamurugan, \& Ranganathan, 2008). Financially, this translates to reduced irrigation costs. The second variable is savings from discontinuing the use of pesticides and fertilizers. In this scenario, we are assuming that one ton of vermicast will completely offset chemical fertilizer use with the same yield, supported by the results from Manivannan et al. (2009) and Singh, R., Sharma, et al. (2008). With far fewer studies comparing vermicast performance to pesticide performance, we assume that one ton of vermicast will offset $75 \%$ of pesticide use, based on data from Sinha et al. (2010). The last variable is the eliminated health care costs associated with acute poisoning from pesticide exposure. Again, this value will be discounted by $25 \%$ since we are still assuming $25 \%$ pesticide use.
Estimating the value of vermicast treatments compared to agrichemical treatment is a considerable undertaking, and clearly more research should be conducted before making conclusions. It is nonetheless worthwhile to take a closer look at the data used to estimate agricultural benefits.

Manivannan et al. (2009) and R. Singh et al. (2008) show through plant growth experiments that the application of one ton of vermicast will increase yield slightly (around 3\%) as compared to the application of the recommended dose of NPK fertilizer. Increased production by 3\% represents greater profits, but because these studies may rely on pampered plants in greenhouses, their results may not apply to crops in more realistic conditions. For this reason, the 3\% benefit was left out of the analysis and we simply assume equal performance between synthetic fertilizers and vermicast.

Several other likely improvements were also left out of the analysis. These include enhanced crop quality and faster growth. R. Singh et al. (2008) report significantly fewer days taken for strawberry plants to flower when treated with vermicast. Also reported are significant improvements in fruit firmness, color, quality (defined by TSS, ascorbic acid, and acidity levels [R. Singh et al., 2008], sugar and protein content [Manivannan et al., 2009; Parthasarathi et al., 2008], and micronutrient content [Peyvast, Olfati, Madeni, \& Forghani, 2008]), and keeping quality (Meerabai, Jayachandran, Asha, 2007). While these characteristics are certainly important in judging the overall benefit of vermicast use, they are not included in the study due to price complexities.

In the cost-benefit analysis, we calculated the benefit of applying one ton of vermicompost to one hectare $(2.47$ acres $)$ of land per year. One study, however, found that a single vermicompost treatment (dosage unknown) improved the yield of cherry trees for three consecutive years (Sinha et al., 2010). Less frequent applications of vermicompost represent significant savings as compared to yearly or seasonally applied fertilizers and pesticides.

Another element that must be taken into consideration is that abandoning the use of agrichemicals could represent a transition to organic agriculture. The farmer who relies solely on vermicast 
inputs would be eligible theoretically to receive premiums for his or her products, and this would significantly increase his or her revenue. In this study we include the use of some pesticides $(25 \%$ of the general requirements), but it is important to keep in mind that larger vermicast applications may offset pesticide use altogether. Additionally, were we to consider a more realistic scenario in which the farmer uses half fertilizer and half vermicast, he or she would most likely benefit from increased yields. This scenario is further explored in Appendix F.

In short, the value estimated in this study of transitioning to a vermicast regimen is an underestimate. Due to a series of probable improvements (enhanced yields, faster growing periods, higher quality, keeping time, organic premiums, and other factors), the actual benefit to the farmer would most likely be greater.

A small farmer profile was compiled to elucidate the finances of the average, small-scale, sugar beet farmer in Lebanon (see Appendix C). Based on this information, the benefits were calculated and totaled (see Appendix D) and, lastly, the cost of purchasing the product was subtracted to generate the net returns. These net returns illuminate the farmer's (consumer's) incentive to invest in vermicast.

\section{Social Cost-Benefit Analysis}

Once the three individual sectors (waste management savings, enterprise opportunities, and agricultural benefits) are examined, they are combined to generate a social cost-benefit analysis. This elucidates the overall impact of producing and applying one ton of vermicast.

\section{Results}

\section{Qualitative Study}

The following four case studies describe examples of the people who have taken up vermicomposting activities, the systems and scales they have adopted, and their perception of vermicomposting and drive to engage.

\section{Maysan in Batloun}

The first case study features the village of Batloun in Lebanon's Shouf area, located at an altitude of 1,080 meters ( 3,543 feet). The climate can be characterized as moderate with dry summers and winters of snow and intense rainfall (Rachid, 2007). One part of Moledor's thesis work was to test a "backyard" vermicomposting microenterprise model in a real village context. An elderly sheikha named Maysan showed interest in participating in the project, which took place between July and November 2013 (since the climate of Batloun prohibits vermicomposting during the coldest months). Unlike the other case studies, Maysan's vermicomposting experience took place within a formal thesis framework. As such, she was paid a small monthly salary as compensation for her time and effort.

The system that Maysan used to vermicompost is referred to as the "backyard" system due to its small scale. It involves using Lebanon's abundant plastic fruit crates, lined with recycled textile. Each crate is filled with organic waste and then multiple crates are stacked vertically to conserve space.

Because waste is divided into these small crates, it is suitable for processing small quantities of waste: in Maysan's case, five households' worth.

Although Maysan had never composted before, she had previous knowledge of the practice. She was familiar with the concept of burying tree leaves in the ground and leaving them for several months to decompose. Regarding earthworms, however, she had quite a different perspective prior to the project. As a gardener, she was always told that worms were bad for plants and that the worms around a weak plant should be removed so that it could recover. Given the novelty of this biotechnology and the unsavory reputation of worms, it was especially pertinent to understand the social reaction to the project. The issue of separating organic waste at the household level was expected to be a hurdle. Surprisingly, Maysan said her neighbors responded well and were happy to participate. Separation was a new concept, but she was pleased that they caught on quickly. She said that they quickly learned to distinguish between waste that should go in the bucket and waste that should go to Sukleen. As for the actual vermicomposting, many people found, and still find, the idea repulsive and did not 
understand what could come of such a project. Her neighbors, even those not involved in waste collection, were accepting nevertheless.

However, what became clear is that, for economies of scale, a larger vermicomposting system would be preferable for processing larger quantities of waste. In light of these findings from the trial in Batloun, larger-scale vermicomposting systems were introduced in subsequent projects (the case studies below).

\section{Georges in Damour}

The next case study took place in the coastal village of Damour. Damour's elevation is between 0 and 200 meters (656 feet), and most of its 10 square kilometers (3.9 square miles) is composed of vegetable agriculture and banana plantations. Georges is a banana farmer and was interested in getting involved with the vermicomposting project being conducted at the university. He uses only organic fertilizers for his trees, but was interested in trying to vermicompost his banana waste (mostly composed of banana leaves and trunks) to obtain a higher quality, lower cost fertilizer.

In December 2014, in collaboration with the American University of Beirut (AUB), he built a vermicomposting basin approximately $1 \mathrm{~m}$ wide by $5 \mathrm{~m}$ long by $.75 \mathrm{~m}$ tall (1.1 yard wide by 5.5 yards long by .82 yard tall) for a total capacity of $3.75 \mathrm{~m}^{3}$ $\left(4.5\right.$ yard $\left.^{2}\right)$. The basin was a simple design constructed of cinderblocks and concrete, and the floor of the basin tilted gently toward one corner where a tube was inserted for water evacuation. Georges filled the basin with banana waste, but it became clear that this material requires substantial time to decompose to a point where it will be edible by worms. Therefore, a shredding machine is strongly recommended to facilitate decomposition.

Georges was already very familiar with the concept of composting. For years he had been placing the banana leaves and trunks in the same pile on his land so that they would decompose and could one day be reapplied as compost. However, banana waste requires years to break down, so this strategy is not very efficient. Even though the basin has yet to deliver any vermicast, he is happy with the project and has considered investing in a shredder and additional basins for increased production that will eventually benefit his banana trees and the health and fertility of his soils.

\section{Khalid in Bchetfine}

Bchetfine is a small village, only $2.5 \mathrm{~km}^{2}\left(0.97 \mathrm{mi}^{2}\right)$ in area, located at 470 meters (1,542 feet) above sea level in the Shouf region of Lebanon. Khalid was formerly a pharmacist and now works in the shipping industry outside Beirut. He owns a small parcel of land near his house where he grows fruits and vegetables. He heard about vermicomposting through a third party and was adamant about taking part in the project.

When presented with a range of options, Khalid chose the barrel vermicomposting system. It involves plastic barrels cut in half their long way to hold the food waste and worms. These barrels are placed on a wooden rack with space for four on top and four below. Khalid's system is just beginning and is not yet up to capacity, but at the time of this writing one barrel worth of household kitchen waste is nearly ready for harvest. After using the first few batches on his own crops, he plans to sell future batches of vermicast.

Khalid is driven by curiosity and is a very thorough researcher. He quickly adapted the vermicomposting process by placing fresh food scraps in transparent plastic bags and letting them sit in the sun in order to jumpstart the precomposting process. When asked about his neighbors' reaction to his newfangled project, he said, "people are always suspicious of what they don't understand."

\section{Nadim in Fanar}

Nadim is the co-owner of an organic plant and tree nursery in the Metn region, near Beirut. His neighborhood is approximately 250 meters (820 feet) in elevation. He was the only known vermicomposting practitioner in Lebanon before the project at AUB.

Employing two large vermibeds, Nadim vermicomposts composted horse manure he obtains from an acquaintance. The manure is loaded into one compartment of the vermibed, and once it has been completely transformed by the earthworms he imported from Europe, he puts fresh manure in 
Table 3. Calculating the Waste Management Benefits of Using Vermicast

\begin{tabular}{lllccc}
\hline Component & \multicolumn{1}{c}{ Sources } & \multicolumn{1}{c}{ Country } & $\begin{array}{c}\text { Cost per ton of } \\
\text { waste (US\$) }\end{array}$ & $\begin{array}{c}\text { Average savings per } \\
\text { ton of vermicompost } \\
\text { produced (US\$) }\end{array}$ \\
\hline Environmental Disamenity & Clarke, 2000 & Australia & $\$ 7$ & $\times 2$ & $\$ 14$ \\
\hline $\begin{array}{l}\text { Waste Collection (Collection, } \\
\text { sweeping, supervision) }\end{array}$ & $\begin{array}{l}\text { Massoud, El-Fadel, } \\
\text { Abdel Malak, 2003 }\end{array}$ & $\begin{array}{l}\text { Lebanon (Beirut } \\
\text { and Tripoli average) }\end{array}$ & $\$ 27$ & $\times 2$ & $\$ 54$ \\
\hline $\begin{array}{l}\text { Processing Costs (Processing, } \\
\text { landfilling, supervision) }\end{array}$ & $\begin{array}{l}\text { Massoud, El-Fadel, } \\
\text { Abdel Malak, 2003 }\end{array}$ & Lebanon (Beirut) & $\$ 62$ & $\times 2$ & $\$ 124$ \\
\hline & & & $\$ 96$ & $\mathbf{\$ 1 9 2}$ \\
\hline
\end{tabular}

the second compartment and the worms migrate across the perforated brick separation wall, making the vermicast easy to harvest. He applies the vermicast directly on his plants and trees or mixes it with irrigation water.

Nadim is an engineer. Having been educated in Lebanon and Austria, he and his family are very dedicated to the concepts of organic and holistic agriculture, which can be seen by his lush, diverse garden. Vermicomposting is a process that he has introduced into his garden ecosystem that provides a constant source of natural fertilizer.

\section{Feasibility Study}

\section{Waste management savings}

The cost of collecting, processing, and landfilling one ton of organic waste is $\$ 96$. To calculate the savings per ton of vermicast produced, this sum must be multiplied by 2 since two tons of organic waste will generate one ton of vermicast (Adhikary, 2012). Thus one ton of vermicast represents $\$ 192$ worth of savings. But who profits from these savings? In response to a reduced waste stream, the Lebanese government would theoretically pay Sukleen less, while local municipalities would spend less on their own solid waste services (see Table 3). Using these values, it becomes clear that if Lebanon were to produce just 100 tons of vermicompost per year, they would be saving the government and/or municipalities $\$ 19,200$ per year $(100 \mathrm{x}$ $\$ 192)$. For an even more dramatic scenario, if a mere $0.1 \%$ of the country's yearly 1.57 million ton waste stream (MoE, 2011) were diverted to vermicomposting facilities, the government and/or municipalities would save $\$ 150,720$. In areas where there are no formal waste management programs, the entire community still stands to benefit from reduced open dumping and a less polluted environment.

\section{Enterprise opportunities}

Once the operating cost was estimated and the theoretical price of vermicast determined (see Tables B1 and B2 in Appendix B), Table 4 was compiled to show the anticipated profits of the vermicompost microenterprise.

In order to determine the quantity of waste that this system is capable of processing per month, consider that the four "vermibeds" collectively hold $480 \mathrm{~kg}$ of predecomposed organic waste at any given time. This represents roughly $600 \mathrm{~kg}$ of fresh organic waste. How many households per month does this account for? If we average the data from Moledor (2014) and Sukleen (S. Chebaclo, Sukleen, personal communication, October 13, 2013), we can assume that the average

Table 4. Generating Net Returns for a Vermicompost (VC) Enterprise in a Lebanese Case Study (US\$)

\begin{tabular}{lc}
\hline Organic waste collected per month (from 27 households) & $600 \mathrm{~kg}$ \\
\hline $\begin{array}{l}\text { Equivalent VC production per month } \\
\text { (based on data from Adhikary, 2012) }\end{array}$ & $300 \mathrm{~kg}$ \\
\hline $\begin{array}{l}\text { Price: } \\
\text { Bulk: } 16 \$ / \mathrm{kg}\end{array}$ & $\times 150 \mathrm{~kg} / \mathrm{mo}=\$ 24$ \\
Pure: $\$ 5 / \mathrm{kg}$ & $\times 150 \mathrm{~kg} / \mathrm{mo}=\$ 750$ \\
\hline Revenue per month & $\$ 774$ \\
\hline $\begin{array}{l}\text { Profits per month } \\
\text { (Revenue minus costs }(\$ 176) \text { ) }\end{array}$ & $\$ 598$ \\
\hline Per ton VC calculations $(\times 3.3$ months to produce a ton) & $\$ 1,973$ \\
\hline
\end{tabular}


Lebanese household generates $22 \mathrm{~kg}$ of organic waste per month. This system will accommodate approximately 27 households on a continuous basis. A population of 10,000-15,000 earthworms will process this waste over the course of a month (using the consumption rate from Moledor, 2014). This leaves us with $300 \mathrm{~kg}$ of vermicast, a reduction of $50 \%$ as suggested in a study by Adhikary (2012). Half the $300 \mathrm{~kg}$ of vermicast will be separated into bulk and half into pure castings, which represents a revenue of $\$ 774$ per month. After subtracting the monthly enterprise costs $(\$ 176)$, the net monthly returns are estimated at $\$ 598$.

For the sake of the greater feasibility study, however, we must determine the value per ton of vermicast. If $300 \mathrm{~kg}$ of vermicast are produced per month in this theoretical business, then approximately 3.3 months are required to produce one ton of vermicast. As such, $\$ 598$ multiplied by 3.3 equals a total of $\$ 1,973$ in net returns per ton.

It is important to consider how the estimated price of vermicast in Lebanon will influence demand. How does the price of bulk vermicast compare to other commonly used fertilizers in Lebanon? The compost produced by Sukomi is of such low quality that it is given away free of charge. Very high-quality compost is priced at $\$ 230$ per ton (Z. Abichaker, Cedar Environmental, personal communication, November 21, 2013). Farmers typically spend about $\$ 70$ per ton for animal manure (MoE, 2001) and between $\$ 136$ and $\$ 260$ for synthetic fertilizers for one hectare of sugarbeet cultivation (see Table C1). So $16 \notin$ per kilogram or $\$ 160$ per ton for bulk vermicast is a reasonable price to expect farmers to pay. In regard to the pure vermicast to be sold at $\$ 5$ per $\mathrm{kg}$, an Internet search reveals that this is the going rate for synthetic lawn and garden fertilizers.

Another important consideration, in addition to price, is performance. A number of studies have examined the nutrient content of vermicompost, compost, and traditional fertilizers. However, any comparison between these products will remain inconclusive since variables such as feed source (food scraps vs. cow manure, for example), duration, and climate will constantly alter the composition of vermicast and compost.

A vermicomposting business, as outlined here, has the potential to be profitable, although probably not lucrative. Predicting each element of a business that does not yet exist requires making many assumptions, and it should be acknowledged that due to many variables such as seasonality, the availability of worms, optimization of the vermicomposting system, unanticipated costs, and overestimated demand, the enterprise analysis should only be considered preliminary, in the absence of more exact data.

\section{Agricultural benefits}

The first step in estimating the value of vermicast application to the farmer is to compile a small farmer profile in order to understand how he or she stands to benefit. This profile is detailed in Table C1 of Appendix C. Appendix D details the calculations used to determine the dollar value of three measures: reduced irrigation requirements (because soil amended with vermicompost has a higher water retention capacity), the foregone costs of chemical inputs (fertilizer and pesticide), and the forgone costs of pesticide-related illness, all enumerated in Table D1.

Finally, what are the net returns to the farmer when he or she buys and applies vermicast? This can be deduced by adding the value of all the benefits from Table D1 and then subtracting the estimated cost of one ton of vermicompost. Note that these net returns are in addition to the farmer's previous income under an (assumed) agrichemical regimen.

The results show that one sugar beet farmer applying one ton of vermicompost stands to gain an additional \$110-\$347 per year (Table 5).

\section{Social Cost-Benefit Analysis}

Up to this point, each sector has been examined separately. While the cost-benefit analyses for the vermicompost enterprise and for the farmer are clearly private, the waste management sector is public.

Table 5. Additional Net Returns for the Farm Level

\begin{tabular}{l|c}
\hline Total Benefit & $\$ 270-\$ 507$ \\
\hline Cost of 1 Ton Vermicompost & $\$ 160$ \\
\hline Net Returns (benefits minus costs) & $\$ 110-\$ 347$ \\
\hline
\end{tabular}


A social cost-benefit analysis usually takes into account private benefits as well as the contribution to the greater good of society (van Kooten, 2013). For the sake of simplifying a very complex analysis, not all environmental and social benefits that vermicomposting can provide could be taken into account. However, combining the benefits from the two private sectors and one public sector is one way to present a more meaningful, cross-sector social cost-benefit analysis of a vermicomposting program in Lebanon.

Table 6 summarizes the entire feasibility study. The net returns for each sector are generated by subtracting the costs from the benefits. They are then totaled to show the anticipated social benefit, or value to society, resulting from the production and consumption of one ton of vermicompost applied on one hectare of sugar beets. The costbenefit ratio is generated by dividing the benefits by the costs. It indicates the benefit per dollar invested, so if the ratio is greater than one, the project will increase real wealth.

Clearly, the net returns are not only positive but are high, indicating that vermicompost production and consumption could be a promising national investment. Gains between $\$ 2,275$ and $\$ 2,512$ would be spread across the three sectors for every ton of vermicast produced. The cost-benefit ratio can't be generated for the landfill sector since it is all benefits without any cost. The vermicompost consumer (the farmer) has a medium ratio, as his or her gains are high with a minimal investment. The vermicompost producer has a high projected ratio: every $\$ 1$ investment will yield $\$ 4.40$ in profits. This ratio is higher than that of Shivakumar et al. (2009), who predicted 3.44 in the case of India, figuring a discount rate of $12 \%$.

\section{Discussion}

The Socioeconomic Promise of Vermicomposting Initiatives

There are many variables to take into consideration and many assumptions to make when exploring vermicomposting potential in Lebanon. This analysis is a preliminary attempt to quantify the financial benefits of a vermicomposting economy in Lebanon, and it considers only the short-term, direct social savings that vermicomposting could offer. Nonetheless, the social net returns $(\$ 2,275$ $\$ 2,512$ ) are so high that undesirable conditions (for example, higher vermicast prices for the farmer or reduced waste management fees) are unlikely to bring them below zero.

What would greatly strengthen the vermicomposting proposition would be to measure the positive externalities accurately and include them in the calculations. For example, Pimentel (2005) estimates the environmental and economic costs of pesticide use to be $\$ 10$ billion annually in the U.S. alone. His estimate includes such factors as:

- the destruction of natural pest enemies;

- crop pollination and honey bee losses;

- bird, fish, and wildlife losses;

- groundwater contamination;

- the cost of pesticide resistance in pests;

- crop damage; and

- governmental expenditures to reduce environmental and social damage resulting from pesticides.

A shift away from traditional pesticides and toward more natural methods would generate far greater savings than can be measured in this limited study. One must also consider that food waste, water, topsoil, and of course vermicompost itself, are all natural resources that have an intangible value to society and to the environment, but must be itemized and reduced to a dollar value (van Kooten, 2013). This cost-benefit analysis is accurate as to the private-sector benefits, but inevitably underestimates the overall good to society.

Table 6. Social Net Returns (US\$ benefit/ton of vermicompost/hectare)

\begin{tabular}{lcccc}
\hline Sector & Benefits (US\$) & Costs (US\$) & Net Returns (US\$) & Cost-Benefit Ratio \\
\hline Waste Management & $\$ 192$ & $\$ 0$ & $\$ 192$ & $\mathrm{n} / \mathrm{a}$ \\
\hline Vermicompost Enterprise & $\$ 2,554$ & $\$ 581$ & $\$ 1,973$ & 4.4 \\
\hline Agricultural Benefit & $\$ 270-\$ 507$ & $\$ 160$ & $\$ 110-\$ 347$ & $1.7-3.2$ \\
\hline Total & & & $\mathbf{\$ 2 , 2 7 5 - \$ 2 , 5 1 2}$ & \\
\hline
\end{tabular}


This project takes advantage of what is currently a market failure- the linear production-toconsumption-to-waste stream-and makes it circular. In such circular systems, "benefits will be obtained, not only by minimising use of the environment as a sink for residuals but-perhaps more importantly — by minimising the use of virgin materials for economic activity" (Andersen, 2007, p. 133). For example, vermicomposting alleviates society's dependence on the environment as a sink for waste via the commodification of the waste stream. Organic waste is transformed into vermicast - a two-for-one resource for the agricultural industry that otherwise depends on unsustainable inputs such as phosphorous extraction for fertilizers (Schröder, Cordell, Smit, \& Rosemarin, 2010) or peat in potting mix (Zaller, 2007).

The strength of the vermicomposting program is that recycling is a business opportunity best suited for rural, farming communities. History shows that Lebanon's small farmers have been increasingly marginalized by the country's laissezfaire economic policies (Rachid, 2007). Political instability and environmental pressures exacerbate the situation (MoE, 2001; Zurayk, 1994), and many are being forced to abandon their agricultural livelihoods and to seek alternative employment or to migrate to urban centers (Rachid, 2007). Given these circumstances, the vermicomposting scheme has not been proposed in its high-tech, large-scale, corporate form, similar to that of North America, but in its decentralized, microscale form resembling that of India. As such, the microenterprise opportunity is captured by those who need it most. Yet it should be recognized that it is not out of charity that disfavored rural communities should be the benefactors, but because it is commercially sensible to take advantage of this reserve of traditional agricultural knowledge and to engage people who will be both financially and personally invested in the operation. This decentralized version is also better suited to Lebanon, since the government is viewed as weak and undependable, which drives individuals to provide their own services.

Not to be overlooked is the promise of vermicompost enterprises on a community level. Local businesses spend more money locally on such things as management, services, and advertising. Their profits tend to be reinvested locally, thereby stimulating, however modestly, the local economy and minimizing economic "leakage." Some studies show that a local business yields two to four times the total local economic impact as compared to a nonlocal business. Besides keeping profits within the community, they reestablish the relationships between producers and consumers, contribute to social cohesion, and reduce negative ecological impacts associated with long-distance trade (namely fossil fuel emissions) (Roseland \& Soots, 2007). Vermicompost practitioners in the Philippines reported that their businesses resulted in better relationships within the community (Adorada, 2007).

There are further off-site, long-term, and farreaching elements of socioeconomic development to consider. In this report, the benefits of vermicomposting are mainly considered in terms of savings on commercial farms. Subsistence farming, on the other hand, can be characterized as laborintensive, low-input food production intended for household consumption. In the face of a precarious market and an absence of agricultural insurance, subsistence farming is sometimes an economically reasonable choice for the poor. Additionally, subsistence farming often has positive health and ecology-related impacts in that they provide diverse, healthy foods and medicines while at the same time serving as "repositories of biodiversity" (Hunter, 2008, p. 34). The potential role of vermicomposting in contributing to the food security of disadvantaged households should also not be overlooked.

Despite extensive cultivation and great biodiversity in Lebanon, the country is a major food importer, producing just $20 \%$ of its own food requirements. This makes it one of the least agriculturally self-sufficient countries in the world (Asmar, 2011; Hunter, 2008). Locally generated waste transformed into a material that will stimulate agricultural production is a circular system that can strengthen a country's local food system. Roep and Wiskerke (2006) summarize the socioeconomic benefits of food systems when production, retail, and consumption are more localized: 
One of the interesting findings in this respect is that direct and regional marketing initiatives do generate additional income and employment for rural regions, although the degree to which they do so differs. In addition they enable synergies with other regional economic activities and often contribute to an increase in job satisfaction and organisational capacity within rural communities, greater consumer trust in food systems, and reductions in food miles or waste. (p. 3)

By contributing, however modestly, to enhanced food security, improved food systems, and local economies, vermicomposting could be a mechanism for improved social well-being. It could also preserve less tangible resources, such as the country's culinary traditions (Hunter, 2008) and agrarian heritage and livelihoods (Zurayk, 1994). In addition, reinforcing rural development ideally would slow the rural-to-urban migration to cities that is already compromised by fragile infrastructure and rapid population growth, especially in light of the recent influx of Syrian refugees to Lebanon. This is linked to government policies committed to balancing development by investing in rural areas instead of focusing solely on urban areas (Lebanese Constitution, 1995). Lastly, vermicomposting is aligned with the government's goal of raising the agricultural sector's contribution to GDP by $2 \%$ (Asmar, 2011).

\section{Challenges}

What are the challenges of integrating a vermicomposting industry into Lebanese society? It is worthwhile to explore briefly the psychology of decisionmaking and behavior that might influence the public's acceptance of vermicomposting. Behavioral economists recognize several phenomena in decision-making, one of which is the public's tendency to stick to the status quo. "Due to limits on time, resources, and intellectual energy, most people do not change their habits unless there are pressing reasons to do so. Research verifies that when confronted with a complex or difficult decision, and in the absence of full information about the alternatives, individuals usually stick with their current position" (Moseley \& Stoker, 2013, p. 6). The "current position" in the Lebanese context is the use of agrichemicals and/or standard animal manure as a fertilizer. This study underlines that the behavioral changes required for separating kitchen waste, initiating earthworm operations, and embracing vermicast may be difficult to achieve.

The interview with Maysan in Batloun revealed that her friends and family were startled that she would be handling worms and waste. Moreover, she had believed that worms were harmful to plants. For these reasons, it is important to consider societal attitudes towards worms and waste. These two items are not of neutral value; attitudes, taboos, and religious beliefs underpin many reactions toward waste reuse practices. Negative values in one society may thwart efforts to adopt new treatment and reuse techniques, while other societies may recognize waste as a resource, particularly where resources are scarce. It is also important to consider that people's positive attitudes toward recycling and conserving resources do not guarantee compliance or changes in their practical behavior. This is true of developed countries, but is more marked in developing countries where there are typically fewer resources available to influence public behavior. The slow process of convincing large numbers of residents of the benefits of redirecting food waste and educating them on meticulous separation-at-source practices have often led initiatives or nongovernmental organizations to seek out single-source organics, such as vegetable markets (Furedy \& Pitot, 2009).

Despite these hurdles, there are reasons to remain cautiously optimistic about organic waste reuse technologies: In principle, most people desire good waste management. Furthermore, customs of organic reuse are still very present in both rural and urban settings of the developing world. In rural communities, in particular, wastes are widely exploited for fuel, fodder, and fertilizer, and are not regarded as "wastes" at all, but as free goods (Furedy \& Pitot, 2009). In Lebanon, many farmers buy and apply goat and cow manure to their soil (MoE, 2001), so the concept of earthworm manure should not be foreign. 


\section{Conclusion}

This study brings attention to Lebanon's linear production-to-consumption-to-waste market economy and proposes vermicomposting biotechnology as one component of a sustainable solution. Many scientific studies attest to the environmental value of earthworms and vermicast in the soil, but few consider its utility as a two-in-one soil amendment and how vermicomposting can be introduced practically in such a way as to maximize positive socioeconomic impacts. Our qualitative study paints a portrait of who is likely to adopt vermicomposting and why, while the feasibility study estimates the economic potential of a vermicomposting industry in Lebanon. It becomes clear that there are very few drawbacks and many advantages to investing in rurally based vermicomposting microenterprises and that such development would have resounding benefits that cannot be captured within the scope of this study. These direct and indirect impacts may be the most difficult to measure and assign a dollar value, but they make the best argument for this biotechnology within a long-term national vision for sustainable and effective solid waste management.

\section{References}

Adhikary, S. (2012). Vermicompost, the Story of organic gold: A review. Agricultural Sciences, 3(7), 905-917. http://dx.doi.org/10.4236/as.2012.37110

Adorada, J. L. (2007). Assessment of vermicomposting as a waste management technology and a livelihood alternative in the Philippines. Journal of Environmental Science and Management, 10(2), 28-39. https://journals.uplb.edu.ph/index.php/JESAM/

Al Jazeera \& Agencies. (2015, July 26). Lebanese protest against waste-disposal process. Al Jazeera. Retrieved from http://www.aljazeera.com/news/2015/ 07/lebanon-beirut-trash-rubbish-crisis150725060723178.html

Albayrak, M., Gunes, E., \& Gulcubuk, B. (2010). The effects of irrigation methods on input use and productivities of sugarbeet in central Anatolia, Turkey. African Journal of Agricultural Research, 5(3), 188-195.

Ali, M. B. (2004). Characteristics and production costs of U.S. sugarbeet farms (Statistical Bulletin No. 974-8). United States Department of Agriculture, Economic Research Service. Retrieved from http://www.ers. usda.gov/media/943070/sb974-8.pdf

Andersen, M. S. (2007). An introductory note on the environmental economics of the circular economy. Sustainability Science, 2(1), 133-140. http://dx.doi.org/10.1007/s11625-006-0013-6

Arancon, N. Q., Galvis, P. A., \& Edwards, C. A. (2005). Suppression of insect pest populations and damage to plants by vermicomposts. Bioresource Technology, 96(10), 1137-1142. http://dx.doi.org/10.1016/j.biortech.2004.10.004

Asmar, F. R. (2011). Country pasture/forage resource profiles: Lebanon. Food and Agriculture Organization of the United Nations. Retrieved from http://www.fao.org/ag/agp/agpc/doc/ Counprof/lebanon/lebanon.html

Atiyeh, R. M., Subler, S., Edwards, C. A., Bachman, G., Metzger, J. D., \& Shuster, W. (2000). Effects of vermicomposts and composts on plant growth in horticultural container media and soil. Pedobiologia, 44(5), 579-590. http://dx.doi.org/10.1078/s00314056(04)70073-6

Brundtland Commission. (1987). Our common future. Oxford, UK: Oxford University Press. Retrieved from http://www.un-documents.net/ocf-02.htm

Clarke, W. P. (2000). Cost-benefit analysis of introducing technology to rapidly degrade municipal solid waste. $W$ aste Management \& Research, 18(6), 510-524.

http://dx.doi.org/10.1177/0734242X0001800602

Doherty, B. A., \& McKissick, J. C. (2000). Market opportunities for biosolids-based vermiculture in Georgia (Special Report No. FR-01-09). Athens, Georgia: Center for Agribusiness and Economic Development, University of Georgia. http://hdl.handle.net/10724/19346

Eastman, B. R., Kane, P. N., Edwards, C. A., Trytek, L., Gunadi, B., Stermer, A. L., \& Mobley, J. R. (2001). The effectiveness of vermiculture in human pathogen reduction for USEPA biosolids stabilization. Compost Science \& Utilization, 9(1), 38-49. http://dx.doi.org/10.1080/1065657X. 2001.10702015

Edwards, C. A., Arancon, N. Q., Vasko-Bennett, M., Askar, A., \& Keeney, G. (2010). Effect of aqueous extracts from vermicomposts on attacks by cucumber beetles (Acalymna vittatum) (Fabr.) on cucumbers and tobacco hornworm (Manduca sexta) (L.) on tomatoes. Pedobiologia, 53(2), 141-148. http://dx.doi.org/10.1016/j.pedobi.2009.08.002 
Environmental Protection Agency. (1997). Full cost accounting for municipal solid waste management: $A$ bandbook (EPA 530-R-95-041). Washington, D.C.: Author.

Furedy, C., \& Pitot, H.-A. (2009). Social factors in the treatment and reuse of organic wastes in developing countries. In H. W. Doelle, S. Rokem, \& M. Berovic (Eds.), Biotechnology: Fundamentals of Biotechnology: Social, educational and political aspects of biotechnology (Vol. 14, pp. 107-123). Oxford, UK: UNESCO-EOLSS.

Gajalakshmi, S., \& Abbasi, S. A. (2004). Earthworms and vermicomposting. Indian Journal of Biotechnology, 3(4), 486-494. http://nopr.niscair.res.in/handle/123456789/5894

Gibson, R. B. (2006). Beyond the pillars: Sustainability assessment as a framework for effective integration of social, economic and ecological considerations in significant decision-making. Journal of Environmental Assessment Policy and Management, 8(3), 259-280. http://dx.doi.org/10.1142/S1464333206002517

Global Property Guide. (2012, July). Lebanese property prices rising, but transactions down. Retrieved from http://www.amcham.org.eg/MENA NewsLetter/ retcontent.asp?pageflag $=67$

Hunter, E. (2008). Food security in rural Lebanon: Links with diet and agriculture (Master's thesis). Université Laval, Quebec, Canada. Retrieved from http://theses. ulaval.ca/archimede/ fichiers/25163/25163.html

Jack, A. L. H., \& Thies, J. E. (2006). Compost and vermicompost as amendments promoting soil health. In N. Uphoff (Ed.), Biological Approaches to Sustainable Soil Systems (pp. 453-466). Boca Raton, Florida: CRC Press. http://dx.doi.org/10.1201/9781420017113.ch31

Karaa, K., Karam, F., \& Tarabey, N. (2004). Participatory water saving management and water cultural heritage: Lebanon country report. In A. Hamdy, M. Tüzün, N. Lamaddalena, M. Todorovic, \& C. Bogliotti (Eds.), Participatory water saving management and water cultural heritage (pp. 185-198). Bari, Italy: CIHEAM. http://om.ciheam.org/ article.php?IDPDF $=5002293$

Kumar, P. R., Jayaram, A., \& Somashekar, R. K. (2009). Assessment of the performance of different compost models to manage urban household organic solid wastes. Clean Technologies and Environmental Policy, 11(4), 473-484. http://dx.doi.org/10.1007/s10098-009-0204-9
Lazcano, C., Gómez-Brandón, M., \& Domínguez, J. (2008). Comparison of the effectiveness of composting and vermicomposting for the biological stabilization of cattle manure. Chemosphere, 72(7), 1013-1019. http://dx.doi.org/10.1016/j.chemo sphere.2008.04.016

Lebanese Constitution. (1995). Retrieved from http://www.presidency.gov.lb/French/LebaneseSy stem/Documents/Lebanese\%20Constitution.pdf

Lleó, T., Albacete, E., Barrena, R., Font, X., Artola, A., \& Sánchez, A. (2013). Home and vermicomposting as sustainable options for biowaste management. Journal of Cleaner Production, 47, 70-76. http://dx.doi.org/10.1016/j.jclepro.2012.08.011

Manivannan, S., Balamurugan, M., Parthasarathi, K., Gunasekaran, G., \& Ranganathan, L. S. (2009). Effect of vermicompost on soil fertility and crop productivity - beans (Phaseolus vulgaris). Journal of Environmental Biology, 30(2), 275-281. http://imsear.hellis.org/handle/123456789/146185

Massoud, M. A., El-Fadel, M., \& Abdel Malak, A. (2003). Assessment of public vs private MSW management: A case study. Journal of Environmental Management, 69(1), 15-24. http://dx.doi.org/ 10.1016/S0301-4797(03)00104-X

Meerabai, M., Jayachandran, B. K., \& Asha, K. R. (2007). Biofarming in bitter gourd (Momordica charantia L.). Acta Horticulturae, 752, 349-352. http://dx.doi.org/ 10.17660/ActaHortic.2007.752.60

Ministry of Environment [MoE]. (2001). Lebanon state of the environment report 2001. Beirut: Lebanese Government/Ministry of Environment, LEDO, and ECODIT. Retrieved from http://www.moe.gov.lb/The-Ministry/Reports/ State-Of-the-Environment-Report-2001.aspx

MoE. (2011). State and trends of the Lebanese environment 2010. Beirut: Lebanese Government/Ministry of Environment, United Nations Development Program (UNDP), and ECODIT. Retrieved from http://www.moe.gov.lb/The-Ministry/Reports $\angle$ State-Of-the-Environment-Report2010.aspx?lang=en-us

Moledor, S. (2014). Exploring technical and economic aspects of vermicomposting as a microenterprise in rural communities of Lebanon (unpublished master's dissertation). The American University of Beirut, Lebanon. Retrieved from https://scholarworks.aub.edu.lb/handle/ 10938/10178?show $=$ full 
Moseley, A., \& Stoker, G. (2013). Nudging citizens? Prospects and pitfalls confronting a new heuristic. Resources, Conservation and Recycling, 79, 4-10. http://dx.doi.org/10.1016/j.resconrec.2013.04.008

Munnoli, P. M., Teixeira da Silva, J. A., \& Bhosle, S. (2010). Dynamics of the soil-earthworm-plant relationship: A review. In J. A. Teixeira da Silva (Ed.), Special Issue II on Vermitechnology: Volume 4 Special Issue 1. Dynamic soil, dynamic plant (pp. 1-21). Global Science Books.

Munroe, G. (2005). Manual of on-farm vermicomposting and vermiculture. Organic Agriculture Centre of Canada. Retrieved from http://www.organicagcentre.ca/docs/vermiculture _farmersmanual_gm.pdf

Murthy, P. S., \& Naidu, M. M. (2012). Sustainable management of coffee industry by-products and value addition-A review. Resources, Conservation and Recycling, 66, 45-58. http://dx.doi.org/10.1016/j.resconrec.2012.06.005

Myers, N., Mittermeier, R. A., Mittermeier, C. G., da Fonseca, G. A. B., \& Kent, J. (2000). Biodiversity hotspots for conservation priorities. Nature, 403, 853-858. http://dx.doi.org/10.1038/35002501

Pavlícek, T., Csuzdi, C., \& Nevo, E. (2003). Species richness and zoogeographic affinities of earthworms in the Levant. Pedobiologia, 47(5-6), 452-457. http://dx.doi.org/10.1078/0031-4056$\underline{00212}$

Parthasarathi, K., Balamurugan, M., \& Ranganathan, L. S. (2008). Influence of vermicompost on the physico-chemical and biological properties in different types of soil along with yield and quality of the pulse crop-blackgram. Iranian Journal of Environmental Health Science \& Engineering, 5(1), 5158. http://hdl.handle.net/1807/62120

Patterson, P. (2009). The economics of growing sugarbeets in southern Idaho: A short run gross margin analysis (Agricultural Economics Extension Series No. 0901). Moscow, Idaho: University of Idaho.

Peyvast, G., Olfati, J. A., Madeni, S., \& Forghani, A. (2008). Effect of vermicompost on the growth and yield of spinach (Spinacia oleracea L.). Journal of Food, Agriculture \& Environment, 6(1), 110-113.

Pimentel, D. (2005) Environmental and economic costs of the application of pesticides primarily in the United States. Environment, Development and
Sustainability, 7(2), 229-252.

http://dx.doi.org/10.1007/s10668-005-7314-2

Purkayastha, R. D. (2012). Forming community enterprises using vermicomposting as a tool for socio-economic betterment. Proceedings of the 2012 International Conference on Economics, Business and Marketing Management, 29.

Rachid, G. K. (2007). Evolution of natural resource management in Mount Lebanon: The case of Batloun 1935-2005 (unpublished master's thesis). The American University of Beirut, Lebanon.

Riggle, D., \& Holmes, H. (1994). New horizons for commercial vermiculture. BioCycle, 35(10), 58-62.

Robert, K. W., Parris, T. M, \& Leiserowitz, A. A. (2005). What is sustainable development? Goals, indicators, values, and practice. Environment: Science and Policy for Sustainable Development, 47(3), 8-21. http://dx.doi. org/10.1080/00139157.2005.10524444

Roep, D., \& Wiskerke, H. (Eds.). (2006). Nourishing networks: Fourteen lessons about creating sustainable food supply chains. Doetinchem: Rural Sociology Group of Wageningen University and Reed Business Information.

Roseland, M., \& Soots, L. (2007). Strengthening local economies. In M. O’Meara Sheehan (Dir.), State of the World 2007: Our Urban Future (pp. 152-169). Washington, D.C.: Worldwatch Institute. https://www.worldwatch.org/files/pdf/State $\% 252$ 0of $\% 2520$ the $\% 2520$ World $\% 25202007$.pdf

Schröder, J. J., Cordell, D., Smit, A. L., \& Rosemarin, A. (2010). Sustainable use of phosphorus (Report 357). Wageningen, the Netherlands: Plant Research International, Wageningen University.

Seenappa, S. N. (2011). Transformation of wet garbage of Indian urbanites at household level. Universal Journal of Environmental Research and Technology, 1(2), 169-175. http://www.environmentaljournal.org

Shivakumar, C., Mahajanashetti, S. B., Murthy, C., Basavaraja, H., \& Hawaldar, Y. N. (2009). Production and marketing of vermicompost in Dharwad District: An economic analysis. Karnataka Journal of Agricultural Science, 22(4), 850-853.

Singh, R., Sharma, R. R., Kumar, S., Gupta, R. K., \& Patil, R. T. (2008). Vermicompost substitution influences growth, physiological disorders, fruit yield and quality of strawberry (Fragaria $\mathrm{x}$ ananassa Duch.). Bioresource Technology, 99(17), 8507-8511. http://dx.doi.org/10.1016/j.biortech.2008.03.034 
Singh, R. P., Embrandiri, A., Ibrahim, M. H., \& Esa, N. (2011). Management of biomass residues generated from palm oil mill: Vermicomposting a sustainable option. Resources, Conservation and Recycling, 55(4), 423-434. http://dx.doi.org/10.1016/j.resconrec.2010.11.005

Singh, R. P., Singh, P., Araujo, A. S. F., Hakimi Ibrahim, M., \& Sulaiman, O. (2011). Management of urban solid waste: Vermicomposting a sustainable option. Resources, Conservation, and Recycling, 55(7), 719-729. http://dx.doi.org/10.1016/j.resconrec.2011.02.005

Sinha, R. K., Agarwal, S., Chauhan, K., Chandran, V., \& Kiranbhai Soni, B. (2010). Vermiculture technology: Reviving the dreams of Sir Charles Darwin for scientific use of earthworms in sustainable development programs. Technology and Investment, 1, 155-172. http://dx.doi.org/10.4236/ti.2010.13019

Sinha, R. K., Herat, S., Agarwal, S., Asadi, R., \& Carretero, E. (2002). Vermiculture and waste management: study of action of earthworms Elsinia foetida, Eudrilus enginae and Perionyx excavatus on biodegradation of some community wastes in India and Australia. Environmentalist, 22(3), 261-268. http://dx.doi.org/10.1023/A:1016583929723

Soares, W. L., \& Porto, M. F. d. S. (2009). Estimating the social cost of pesticide use: An assessment from acute poisoning in Brazil. Ecological Economics, 68(10), 2721-2728. http://dx.doi.org/10.1016/j.ecolecon.2009.05.008

Tognetti, C., Laos, F., Mazzarino, M. J., \& Hernandez, M. T. (2005). Composting vs. vermicomposting: A comparison of end product quality. Compost Science
\& Utilization, 13(1), 6-13. http://dx.doi.org/ 10.1080/1065657X.2005.10702212

Tognetti, C., Mazzarino, M. J., \& Laos, F. (2007). Improving the quality of municipal organic waste compost. Bioresource Technology, 98(5), 1067-1076. http://dx.doi.org/10.1016/j.biortech.2006.04.025

van Kooten, G. C. (2013). How economists measure wellbeing: Social cost-benefit analysis. In G. C. van Kooten (Ed.), Climate Change, Climate Science and Economics: Prospects for an Alternative Energy Future (pp. 179-220). Dordrecht, Netherlands: Springer Science + Business Media. http://dx.doi.org/10.1007/978-94-007-4988-7 6

Vermani, S. (2007). Empowerment of farmers through vermi-compost in rural communities of Haryana. Haryana Journal of Horticultural Science, 36(3\&4), 415-418.

World Bank. (2010). Republic of Lebanon water sector: Public expenditure review (Report No. 52024-LB). Retrieved from http://www-wds.worldbank.org/external/ default/WDSContentServer/WDSP/IB/2010/07/ 16/000334955_20100716015831/Rendered/PDF/ 520241LB0ESW0B110Disclosed0July0141.pdf

Zaller, J. G. (2007). Vermicompost as a substitute for peat in potting media: Effects on germination, biomass allocation, yields and fruit quality of three tomato varieties. Scientia Horticulturae, 112(2), 191-199. http://dx.doi.org/10.1016/j.scienta.2006.12.023

Zurayk, R. A. (1994). Rehabilitating the ancient terraced lands of Lebanon. Journal of Soil and Water Conservation, 49(2), 106-112. 


\section{Appendix A. Calculating Waste Management Savings}

Environmental disamenity, as defined by Clarke (2000), accounts for gas emissions, site and haulage disamenity (odors, noise, ill repute), and groundwater contamination. Waste collection includes collection, sweeping, and general supervision, and the processing costs include processing, landfilling, and general supervision (Massoud, El-Fadel, \& Abdel Malak, 2003). Both variables are predicted to decrease in response to a decreased waste stream. Altogether, the cost per ton of waste is an estimated $\$ 96$ (Table 3). This estimate is low compared to the findings of Massoud et al. (2003), who proposed a range between $\$ 98$ and $\$ 235$ per ton for middle-income countries such as Lebanon. It is worth noting, also, that the social costs of landfilling are not entirely accounted for in the $\$ 96$ estimate due to measurement difficulties. These include the decline in nearby property values, the opportunity costs of alternative and future land uses, and the impact on quality of life (Environmental Protection Agency, 1997).

Keeping in mind that our feasibility study is based on the value of one ton of vermicompost, the cost per ton of waste $(\$ 96)$ is then multiplied by two since earthworms consume organic waste and reduce its volume by approximately $50 \%$ (Adhikary, 2012). In other words, each ton of vermicompost is the product of two tons of organic waste. As such, Table 3 estimates that for each ton of vermicompost produced, $\$ 192(\$ 96 \times 2)$ worth of costs are averted within Lebanon's waste management program. 


\section{Appendix B. Calculating Enterprise Opportunities}

Calculating enterprise opportunities involves a micro-cost analysis to show the financial dynamics of a vermicomposting enterprise. More specifically, it estimates the input cost required to initiate and sustain a business and compares it to anticipated profits. This micro-cost analysis is based on work previously commissioned by one Lebanese vermicomposting practitioner and, in some cases, on estimates. It should be noted that a variety of vermicomposting methods and materials exist that may increase or decrease the capital costs.

The components in Table B1 are the fixed costs or the costs that remain the same regardless of the output level. Equipment and supplies are expected to last approximately 5 years before requiring maintenance or repair. Because the feasibility study is calculated on a monthly basis, we can divide the sum by 60 months ( 5 years), which spreads the total fixed costs across the first 60 months of operation, basically transforming them into a monthly expenditure.

Table B1. Fixed Costs of an Existing Vermicompost Microenterprise in Lebanon

\begin{tabular}{lccc}
\hline Component & $\begin{array}{c}\text { Individual Cost } \\
(\text { US } \$)\end{array}$ & $\begin{array}{c}\text { Quantity } \\
\text { Vermibeds }\end{array}$ & $\begin{array}{c}\text { Total Cost } \\
(\text { US } \$)\end{array}$ \\
\hline Shade Pergola & $\$ 280$ & 4 & $\$ 1,120$ \\
\hline Water Pond & $\$ 320$ & 1 & $\$ 320$ \\
\hline Worms & $\$ 300$ & 1 & $\$ 300$ \\
\hline $\begin{array}{l}\text { Supplies (shovels, compost bins, } \\
\text { gloves, hand-crank filter) }\end{array}$ & $\$ 200$ & & $\$ 200$ \\
\hline Total Fixed Costs & $\$ 450$ & & $\$ 450$ \\
\hline$\div 60$ months (5 years) & & & $\$ 2,390$ \\
\hline
\end{tabular}

Table B2 shows the variable costs (whose quantities will vary according to output) calculated on a monthly basis. Vermicast transportation and delivery expenses were not included because we are assuming local production and usage. Imputed rent (also known as opportunity cost) is calculated by using the following formula:

$$
\text { Monthly rent }=\frac{3 \%\left(\text { cost of land per } \mathrm{m}^{2}\right)}{12 \text { months }}
$$

Assuming an average cost of $\$ 100 / \mathrm{m}^{2}$ for land and a plot of land measuring $8 \times 8$ meters, $\$ 16$ per month is a reasonable estimate for monthly rent (based on data from Global Property Guide, 2012).

Once the fixed and variable costs are estimated, they can be added together $(\$ 40+\$ 136)$ to express the monthly operating expenses of a vermicomposting enterprise at $\$ 176$. 
Table B2. Variable Costs of an Existing Vermicompost Microenterprise in Lebanon

\begin{tabular}{|c|c|c|c|}
\hline Component & $\begin{array}{l}\text { Individual } \\
\text { Cost (US\$) }\end{array}$ & Quantity & $\begin{array}{l}\text { Total Cost } \\
\text { (US\$) }\end{array}$ \\
\hline Imputed rent & & & $\$ 16$ \\
\hline $\begin{array}{l}\text { Marketing/ } \\
\text { Promotion }\end{array}$ & $\$ 50 /$ month & & $\$ 50$ \\
\hline Maintenance & $\$ 50 /$ month & & $\$ 50$ \\
\hline Water & $\$ 5 /$ month & & $\$ 5$ \\
\hline Bags for Distribution & $50 \phi$ & 30 & $\$ 15$ \\
\hline
\end{tabular}

Now, we must tackle the question of vermicast price. Here, it is helpful to consider a break-even scenario: the minimum price for one ton of vermicast that covers production expenses. According to this model, $300 \mathrm{~kg}$ of vermicast are produced per month, so it would require approximately 3.3 months to produce one ton. The total expenses incurred during this production time would then be $\$ 176$ (in monthly expenses) x 3.3, which means that one ton of vermicast would have to sell at $\$ 581$ to simply break even.

Is it reasonable to expect to receive $\$ 581$ per ton? This price is too high for farmers who pay $\$ 60-\$ 80$ per ton for animal manure (MoE, 2001), \$230 per ton of high-quality compost (Z. Abichaker, Cedar Environmental, personal communication, November 21,2013$)$, and $\$ 136-\$ 260$ per year for synthetic fertilizers (see Table C1 in Appendix C). In order to keep the costs low enough for struggling small farmers to afford, but at the same time make the enterprise profitable, we propose to diversify the product. If the vermicast is sifted or filtered, the purer, more potent vermicast can be separated from the bulk. The pure vermicast, of interest to gardeners and horticulturalists, can be sold in small quantities at higher price compared to the lower-quality bulk vermicast, whose price essentially can be subsidized for small farmers who need it in large quantities for their fields. For the purposes of this study, pure and bulk vermicast are priced at $5 \$$ and $16 \phi$ per kilogram, respectively, based on prices in developed countries found on the Internet. Hence the combined costs of pure (expensive) vermicast and bulk (affordable) vermicast will ensure that production is profitable. Diversifying vermicast quality in this manner is standard procedure in the vermicompost markets of North America and Europe (Munroe, 2005).

From a business point of view, it may be most realistic to sell only high-quality vermicast at a premium in the beginning until subsidizing the bulk cost for farmers becomes a financial possibility. This study, however, assumes the former scenario of selling half pure and half bulk vermicast. 


\section{Appendix C. Calculating the Small-Scale Sugar Beet Farmer Profile}

Calculating the benefits on the farm requires first compiling a small-farmer profile. This profile particularizes how much the farmer spends per hectare per year in Lebanon. Based on this information, it will become clear how much money is to be gained or saved with the use of vermicast.

It should be noted that the data is based on sugar beet farmers. A cost-benefit analysis based on one individual crop, instead of a typical, diversified small farm, provides more specific and accurate data for measuring vermicompost effects. Sugar beet is a common crop grown throughout the country, particularly in the Beqaa Valley. Industrial crops (sugar beet, tobacco, and vineyards) constitute about $10 \%$ of the cultivated land in Lebanon and they require middle-of-the-road quantities of pesticides as compared to other crops (MoE, 2001). As such, the cost-benefit analysis is tailored to sugar beet cultivation but was chosen so as to be representative of many different crops.

It is important to keep in mind that the numbers in Table $\mathrm{C} 1$ are estimates. The studies that form the basis of these estimates are indicated in the chart, along with the year of publication and the country, to show relevance. Some data were greatly contrasting and in these cases are presented as a range.

Table C1. Estimated Input Costs for Small-Scale Sugar Beet Production in Lebanon

\begin{tabular}{|c|c|c|c|c|}
\hline Component & Source & Source Country & $\begin{array}{c}\text { Cost }(\$) / \\
\text { hectare/year }\end{array}$ & $\begin{array}{c}\text { Average \$/ } \\
\text { hectare/year }\end{array}$ \\
\hline Fertilizer Costs & $\begin{array}{l}\text { Ali, } 2004 \\
\text { Albayrak, Gunes, \& Gulcubuk, } 2010\end{array}$ & $\begin{array}{l}\text { USA } \\
\text { Turkey }\end{array}$ & $\begin{array}{l}\$ 136 \\
\$ 260\end{array}$ & $\$ 136-\$ 260$ \\
\hline $\begin{array}{l}\text { Pesticide } \\
\text { Costs }\end{array}$ & $\begin{array}{l}\text { Ali, } 2004 \\
\text { Albayrak et al., 2010; } \\
\text { Patterson, 2009; } \\
\text { MoE, } 2001\end{array}$ & $\begin{array}{l}\text { USA } \\
\text { Turkey/USA/Lebanon }\end{array}$ & $\begin{array}{c}\$ 215 \\
\$ 60-\$ 224\end{array}$ & $\$ 138-\$ 220$ \\
\hline Irrigation Costs & $\begin{array}{l}\text { Karaa, Karam, \& Tarabey, } 2004 \\
\text { World Bank, } 2010\end{array}$ & Lebanon & $\$ 425$ & $\$ 425$ \\
\hline Pesticide Health Costs & Soares \& Porto, 2009 & Brazil & $\begin{array}{c}(8 \%-84 \% x \\
\$ 87.58)\end{array}$ & $\$ 7-\$ 74$ \\
\hline
\end{tabular}

Fertilizer costs per hectare of sugar beet cultivation are estimated between $\$ 136$ and $\$ 260$, according to studies by Ali (2004) and Albayrak et al. (2010). Although Ali (2004) studied beet production in the United States, the costs included here for fertilizer and pesticide are those estimated for low-earning, small family farms, a more valid comparison to small farmers in Lebanon.

The estimated pesticide expenditures of the Lebanese small farmer are compiled by averaging two prices: that of Ali (2004) and a second estimation generated from multiple sources. In the U.S., the cost of pesticides for sugar beets is approximately $\$ 7 / \mathrm{kg}$ (Patterson, 2009) while they are approximately $\$ 26 / \mathrm{kg}$ in Turkey (Albayrak et al., 2010). The range, therefore, is $\$ 7-\$ 26 / \mathrm{kg}$ of pesticides in sugar beet production. Since 8.6 $\mathrm{kg} / \mathrm{ha}$ of pesticides are used annually in sugar beet fields in Lebanon (MOE, 2001), this yields a cost of $\$ 60$ $\$ 224 /$ ha. So, the final estimated cost of pesticide use is the average of these numbers and that proposed by Ali (2004).

Sugar beets in the Beqaa require approximately $850 \mathrm{~mm} /$ ha of water per year (Karaa et al., 2004), equal to $8,500 \mathrm{~m}^{3}$ per year $(850 \mathrm{~mm} \times 100 \mathrm{~m} \times 100 \mathrm{~m})$. If the volumetric price of water in the Beqaa is $\$ 0.05 \mathrm{per}^{2}$ (World Bank, 2010), this means that the average beet farmer spends $\$ 425$ per year for irrigation.

The study by Soares and Porto (2009) quantifies the benefits of pesticide use in relation to the cost of health problems. Their study in Brazil found that pesticide use increases maize productivity by $\$ 87.58 /$ ha, but 
that health costs average anywhere between $8 \%$ and $84 \%$ of this sum, or $\$ 7 /$ ha to $\$ 74 /$ ha. For the purposes of this study, it is assumed that these calculations apply in Lebanon as well. Therefore the medical costs incurred as a result of pesticide exposure ranges from $\$ 7$ to $\$ 74$ per hectare. 


\section{Appendix D. Calculating the Agricultural Benefit per Ton of Vermicast}

In Table D1, the "Benefit" column shows the percent benefit or gain per ton of vermicast applied. The last column shows how much money this represents as a function of the farmer's yearly income. In the case of "Reduced Irrigation Requirements," the 6\% benefit was multiplied by the farmer's estimated irrigation costs from Table C1 (\$425) to determine how much one ton of vermicast will save in this category.

Table D1. Estimated Benefit/Ton/Hectare of Vermicompost (VC) Application

\begin{tabular}{|c|c|c|c|c|c|}
\hline Category & Component & Reference & Country & $\begin{array}{l}\% \text { benefit/ } \\
\text { ton VC }\end{array}$ & $\begin{array}{c}\text { Average US\$ } \\
\text { gain/ton/ha VC }\end{array}$ \\
\hline \multirow{3}{*}{ On-farm Benefits } & \multirow{3}{*}{$\begin{array}{l}\text { Reduced Irrigation } \\
\text { Requirements }\end{array}$} & $\begin{array}{l}\text { Manivannan et al., } \\
2009\end{array}$ & India & \multirow{3}{*}{$6 \%$} & \multirow{3}{*}{$\$ 26$} \\
\hline & & $\begin{array}{l}\text { Parthasarathi et al., } \\
2008\end{array}$ & India & & \\
\hline & & Adhikary, 2012 & India & & \\
\hline \multirow{3}{*}{ Averted Costs (fixed) } & $\begin{array}{c}\text { Fertilizer } \\
\text { (100\% averted) }\end{array}$ & See Table C1 & U.S., Turkey & & $\$ 239-\$ 425$ \\
\hline & $\begin{array}{c}\text { Pesticides } \\
\text { (75\% averted) }\end{array}$ & See Table C1 & $\begin{array}{l}\text { U.S., Turkey, } \\
\text { Lebanon }\end{array}$ & & $\$ 103-\$ 165$ \\
\hline & $\begin{array}{l}\text { Pesticide IIIness } \\
\text { (75\% averted) }\end{array}$ & Soares \& Porto, 2009 & Brazil & & $\$ 5-\$ 56$ \\
\hline Total Benefit & & & & & $\$ 270-\$ 507$ \\
\hline
\end{tabular}

The scenario in Table D1 represents a transition from full agrichemical use (in recommended doses) to full vermicompost use. Since these studies have shown vermicast to enhance crop productivity at least as well as typical doses of inorganic fertilizers, and this scenario assumes that beet farmers in Lebanon are using the recommended doses, then we can infer that vermicast will meet $100 \%$ of the farmer's fertilizer requirements. Knowing that vermicast may drastically decrease the incidence of disease, disorder, and damage by pests (Arancon, Galvis, \& Edwards, 2005; Edwards, Arançon, Vasko-Bennett, Askar, \& Keeney, 2010; Jack \& Thies, 2006; R. Singh et al., 2008), our scenario assumes that vermicast will meet $75 \%$ of pesticide requirements (Sinha et al., 2010).

The average dollar gain (Table D1, last column) translates the percent benefits into a dollar value based on the information compiled in the small-farmer profile (Table C1). "Reduced Irrigation Requirements" benefits were calculated by multiplying the farmer's yearly irrigation expenditure of $\$ 425$ by $6 \%$. This indicates that the enhanced water-holding capacity of the vermicompost-treated soil could save the farmer $\$ 26$ per year in irrigation requirements.

The "Averted Costs" section of the table represents the foregone costs of fertilizer and pesticides and the savings in health costs associated with pesticide abandonment ("Savings on Pesticide Illness"). These figures are fixed because they are incurred regardless of the rate of vermicast application. 


\section{Appendix E. Calculating the Small Farmer's Yearly Revenue (from Agricultural Activity)}

No data could be found regarding the average income of the small-scale sugar beet farmer. Multiple sources at AUB's Faculty of Agriculture and Food Science suggested that $\$ 600$ per month is the minimal subsistence income that could support a small family, of which two-thirds is probably derived directly from agriculture and the other one-third from other forms of employment. Asmar (2011) confirms a high rate of diversification within the agricultural sector in Lebanon; livelihoods are seldom based solely on commercial agriculture but are usually accompanied by other economic inputs. Therefore if a farmer earns $\$ 600$ per month, approximately $\$ 400$ comes directly from his or her agricultural activity, representing an annual income of $\$ 4,800$ ( $\$ 400 \times 12$ months) directly from agricultural activities. Although the average farm size in Lebanon is about 1.25 hectares (MoE, 2001), we rounded this to one hectare, such that one sugar beet farm of one hectare yields the farmer income of $\$ 4,800$ per year. 


\section{Appendix F. 50/50 Vermicast to Fertilizer Scenario}

Farmers may be reluctant to completely abandon agrichemicals in favor of vermicast and may opt instead to use half the recommended dose of each. In this scenario, the total benefits of using 1 ton of vermicast $\$ 270$ $\$ 507)$ are divided by $2(\$ 135-\$ 254)$. From this range we subtract the cost of half a ton of vermicast $(\$ 160 \div 2$ $=\$ 80)$, which leaves a net benefit of $\$ 55-\$ 174$. This may not present a very convincing case for vermicast except that vermicast/fertilizer combinations may increase yield significantly more than when each is used exclusively. For example, bean plants grown under a 50/50 treatment (half recommended dose of NPK fertilizer and half recommended dose of vermicast [2.5 tons]) outperformed bean plants treated with the full dose of NPK fertilizer by 40\% (Manivannan et al., 2009). 